\title{
CHEMICAL CONTROL OF TASMANIAN GRASS GRUB IN THE NORTHERN NORTH ISLAND
}

\author{
R. EAST, B.E. WILLOUGHBY, N.A. HAIGH and N.R. WRENN \\ Ruakura Soil and Plant Research Station, MAF, Hamilton
}

Summary

Foliar sprays of fenitrothion $(1.0$ and $2.0 \mathrm{~kg} / \mathrm{ha})$, isazophos $(1.0$ $\mathrm{kg} / \mathrm{ha})$ and cypermethrin $(0.05$ and $0.10 \mathrm{~kg} / \mathrm{ha})$ in early May gave 98 to $100 \%$ reductions in Tasmanian grass grub (Aphodius tasmaniae) larval populations in pasture at Awhitu Peninsula, Manukau Harbour. Varying the date of spraying with fenitrothion revealed that this high level of control was restricted to applications made before June. Larval feeding is completed earlier in the northern North Island than in Canterbury, where a high level of control can be achieved until July (Read 1969). Insecticidal baits were ineffective against Tasmanian grass grub.

\section{INTRODUCTION}

Tasmanian grass grub, an important pasture pest in south-eastern Australia, was first recorded in Canterbury in 1920 but was not reported to cause severe pasture damage in New Zealand until the late 1960's. The biology and pest status of this insect in New Zealand were reviewed by Pottinger (1968). Tasmanian grass grub is unusual among pasture scarabs in that the larvae are not root feeders but construct tunnels and feed nocturnally on the foliage of pasture plants in a similar manner to porina caterpillar (Wiseana spp.). At present high populations of Tasmanian grass grub are frequently encountered within two localised areas of New Zealand: coastal midCanterbury, and the Awhitu Peninsula of the southern shore of Manukau Harbour south-west of Auckland. A recent survey by Farm Advisory Division, MAF, indicated that about 2,000 ha are infested in each of these areas (R.C. Schofield, pers comm).' Scattered, smaller pockets of infestation occur in North Canterbury, Marlborough, Hawkes Bay, Auckland and Northland.

Read (1969) showed that fenitrothion and several other organophosphate insecticides gave better than $90 \%$ control of Tasmanian grass grub larvae in Canterbury if applied as either foliar sprays or surface broadcast granules before August. In recent years Awhitu Peninsula farmers have reported several failures of the standard control recommendation, viz., spraying with fenitrothion $(1 \mathrm{~kg} / \mathrm{ha})$ at the appearance of pasture damage in early to mid-winter. This study was carried out to investigate the cause of these failures, with particular regard to time of spraying, and to test the effects of a synthetic pyrethroid insecticide and insecticidal baits on Tasmanian grass grub.

\section{METHOD}

Three trials were carried out at Te Toro, on the Awhitu peninsula near Waiuku, one in 1978 and two in 1979. All trials were of a randomized block design. Spray treatments were applied to short, dry pasture with a small plot precision sprayer at 200 $\mathrm{kPa}$ in 300 litres/ha. Granular formulations and baits were applied by hand shaker. Larval populations were assessed by taking twenty five $10 \mathrm{~cm}$ diameter cores (Kain and Young 1975) per plot and extracting the grubs by hand sorting.

Trial 1 compared four chemicals and two formulations (Table 1). Plot size was 4 $x 4 \mathrm{~m}$ with four replicates separated by $5 \mathrm{~m}$ wide buffers. Each replicate was situated on visibly damaged pasture.

Trial 2 compared three chemicals applied as sprays, with the higher rate of fenitrothion applied at three times (Table 2). Plot size was $6 \times 6 \mathrm{~m}$ with six replicates.

Proc. 33rd N.Z. Weed and Pest Control Conf. 


\section{Pasture Scarabs}

Plots were presampled (10 cores per plot) on 1 May 1979 and rejected if they contained less than 120 larvae per $\mathrm{m}^{2}$.

Trial 3 was immediately adjacent to trial 2 and investigated the effects of lucerne meal baits containing fenitrothion (Table 3 ) on larval populations. Baits were prepared 24 hours before application. A standard black field cricket (Teleogryllus commodus) bait (maldison/chipped maize) was included for comparison. Plot size and number of replicates were as in trial 2.

\section{RESULTS AND DISCUSSION}

In trial 1 (late June application) only fensulfothion granules gave a significant reduction in larval numbers in the year of treatment (Table 1) but the level of contro was poor (37\%) and did not extend into the following year. Lindane gave good control one year after treatment. The other treatments were not sampled in the second year. These results contrast with those of Read (1969) who found that the three organophosphates in Table 1 all gave good control in Canterbury when applied in June or July, while organochlorines (lindane and DDT) gave effective control in both the year of application and the subsequent year when applied in late June.

TABLE 1: Tasmanian grass grub larval populations in trial 1 (treated 28 June 1978)

\begin{tabular}{|c|c|c|c|}
\hline Insecticide & Rate (kg/ha) & & \\
\hline Granular formulations & & 17.8.78 & 3.5.79 \\
\hline $\begin{array}{l}\text { lindane } \\
\text { fensulfothion } \\
\text { diazinon } \\
\text { fenitrothion }\end{array}$ & $\begin{array}{l}1.0 \\
1.0 \\
1.0 \\
1.0\end{array}$ & $\begin{array}{l}438 \text { NS } \\
327^{*} \\
500 \text { NS } \\
419 \text { NS }\end{array}$ & $\begin{array}{r}51^{* *} \\
520^{*}\end{array}$ \\
\hline Sprays & & & \\
\hline $\begin{array}{l}\text { fenitrothion } \\
\text { fenitrothion } \\
\text { diazinon } \\
\text { control }\end{array}$ & $\begin{array}{l}2.0 \\
1.0 \\
1.0 \\
-\end{array}$ & $\begin{array}{l}385 \text { NS } \\
539 \text { NS } \\
485 \text { NS } \\
522\end{array}$ & 667 \\
\hline
\end{tabular}

All of the treatments applied in early May in trial 2 gave 98 to $100 \%$ control (Table 2) and there was a marked effect of application time on the level of control with fenitrothion $(P-0.01)$. Since less than 5 weeks had elapsed between the final treatment date and the assessment of larval populations in this trial, the populations of the final treatment with fenitrothion and the control plots were reassessed in late September 1979 to check that mortality was complete at the earlier assessment. This revealed a reduction in larval numbers of $47 \%$ below control, almost identical to that obtained in the previous sampling (Table 2 ).

TABLE 2: Tasmanian grass grub larval populations in trial 2.

\begin{tabular}{lccc}
\hline Insecticide & Rate (kg/ha) & Treatment Date (1979) & No./ $\mathbf{m}^{\mathbf{2}} \mathbf{( 7 . 8 . 7 9 )}$ \\
\hline isazophos & 1.0 & 3 May & 0 \\
cypermethrin & 0.05 & 3 May & 1 \\
cypermethrin & 0.10 & 3 May & 2 \\
fenitrothion & 1.0 & 3 May & 2 \\
fenitrothion & 2.0 & 3 May & 1 \\
fenitrothion & 2.0 & 6 June & 22 \\
fenitrothion & 2.0 & 5 July & 49 \\
control & - & - & 95 \\
\hline
\end{tabular}


The results in Tables 1 and 2 indicate that fenitrothion $(1.0 \mathrm{~kg} / \mathrm{ha})$ should be applied before June in the northern North Island to obtain a high level of control of Tasmanian grass grub, i.e., the period of most effective treatment ends two months earlier than in Canterbury (Read 1969). This probably reflects the more rapid larval development in the milder autumn/winter climate of the northern North Island. Observations at the trial sites revealed that 50 to $75 \%$ of the population had completed larval feeding and entered the inactive prepupal stage by late July whereas this does not occur until September in Canterbury (Pottinger 1968; Kelsey 1969). Spraying in late autumn (April/May) is also less likely to encounter frosty weather which inhibits larval feeding activity and hence exposure to insecticide.

Although Tasmanian grass grub larvae are similar to porina caterpillar in feeding habits they were highly susceptible to cypermethrin (Table 2), unlike porina which has an unusually low susceptibility to synthetic pyrethroids (du Toit et al. 1978). Tasmanian grass grub might be expected to be susceptible to insecticidal baits and hence to reduced rates of insecticide compared to spraying, in a similar manner to other surface-active pasture insects such as black field cricket (Smith 1966) black beetle (Heteronychus arator) adults (R.N. Watson pers comm) and porina (Kain et al. 1979). Although individual treatments in trial 3 reduced larval populations by up to $35 \%$ compared to the control (Table 3), these reductions and the differences between the rates of fenitrothion and lucerne meal bait were not significant $(P-0.05)$. Lucerne meal was chosen because Tasmanian grass grub larvae feed readily on legumes and can seriously damage lucerne stands (Pottinger 1968), and the pasture at the trial sites was predominantly ryegrass (Lolium perenne) and Poa annua with a low content of clover (Trifolium spp.). Baiting appears to be less effective than spraying for control of Tasmanian grass grub.

TABLE 3: Tasmanian grass grub larval populations in trial 3 (treated 3 May 1979).

\begin{tabular}{lcccc} 
Insecticide & Rate (kg/ha) & Bait $^{*}$ & Rate (kg/ha) & No./ $\mathbf{m}^{\mathbf{2}}$ (7.8.79) \\
\hline fenitrothion & 0.15 & $\mathrm{~L}$ & 10 & 55 \\
fenitrothion & 0.30 & $\mathrm{~L}$ & 10 & 53 \\
fenitrothion & 0.15 & $\mathrm{~L}$ & 20 & 78 \\
fenitrothion & 0.30 & $\mathrm{~L}$ & 20 & 67 \\
maldison & 0.125 & $\mathrm{M}$ & 10 & 82 \\
control & - & - & - & 81 \\
\hline
\end{tabular}

${ }^{*} \mathrm{~L}=$ lucerne meal, $\mathrm{M}=$ chipped maize

ACKNOWLEDGEMENT

Mr I. Pellow for the provision of trial sites.

\section{REFERENCES}

du Toit, G.D.G., Townsend, R.J. and Armstrong, S.J., 1978. Lack of response in porina (Wiseana sp.: Hepialidae) caterpillar to treatment with pyrethroid insectìcides. N.Z. J. Exp. Agric. 6: 175-6.

Kain, W.M. and Young, J., 1975. Population studies of Costelytra zealandica (White) 1. A soil sampler suitable for sampling pastureland. N.Z. J. Exp. Agric. 3:177-80.

Kain, W.M., Holland, T.V. and Henzell, R.F., 1979. Feeding studies on Wiseana spp. Proc. 2nd Australasian Conf. Grassland Invert. Ecol. : 270-4.

Kelsey, J.M., 1969. Aphodius in Canterbury. Proc. 22nd N.Z. Weed and Pest Control Conf. : 287-9.

Pottinger, R.P., 1968. Tasmanian grass grub Aphodius tasmaniae Hope a pest of light land pasture and lucerne. Canty. Chamber of Commerce Agric. Bull. 465, 7p

Read, P.E.C., 1969. Control of Aphodius howitti Hope (Coleoptera: Aphodiinae) in Canterbury. Proc. 22nd N.Z. Weed and Pest Control Conf.: 290-5.

Smith, A.G., 1966. Residual effectiveness of poison-baits used for cricket control. Proc. 19th N.Z. Weed and Pest Control Conf.: 222-5. 